【セッション】

\title{
2. 中小食品企業における製品開発戦略
}

林一雄氏（農協流通研究所）の「農林水産 業の食品関連企業との提携による地場農産 加工の展開」、斉藤隆氏（N T T データ通 信）の「消費者ニーズの多様化と商品開 発」、針塚藤重氏「有機農産物を原料とした 加工事業のあり方」の、3 報告が行われた。

林報告の概要は農協などの農林水産業 が、食品関連企業との提携によって、双方の メリットが生まれることを、事例によって 示した。

農林水産業では、製造ノウハウや消費者 ニーズに合った製品開発などの、食品製造 企業では、貴重で良質な原料を使用した製 品の品揃えが出来たなどのメリットがあっ た。

農協側には意志決定の遅さや幹部の説得 力の無さがあり、企業側はコスト意識が強 すぎる短期的な視野に陥りすぎる、などの 問題点が指摘された。しかし、農林水産業の 加工事業は中小企業レベルであり、自力で の開発は時間がかかりすぎために、今後も このような連携が続けられることが必要で あるとする。

斉藤氏の報告は、現在所属企業で開発さ れている、ジャパンV A L S を中心にして 行われた。

現在のマーケティング情報は、結果と原 因が「グチャグチャ」であり、製品開発情報 としてはほとんど役立たないと指摘して、 「価值観」と「活力」の 2 つの軸で、消費者 をセグメントするマーケティング情報のモ デルを提案した。

そして、そのモデルを独自のシステムで

\section{高千穂商科大学 梅沢 昌太郎}

発展させた、「食卓マーケティング情報シス テム」を紹介して、新しい消費者情報のあり 方を提案した。それは現在のP O S のよう な店頭情報ではなく、消費者の家庭の食卓 にどのような食品が素材として使われたか を、分析するシステムであるという。それを 使うことによって、「見たくても見えなかっ た市場が見える」のであると強調する。

針塚氏の報告は、有機農産物を自分で栽 培し、自分で加工し、販売している、実体験 を基にしたユニークなものであった。

氏の理念は生命を育て、それを基本にし て有機農業を展開するということである。 そして、有機農産物を原料とする加工事業 は、日本の風土に根ざした歴史的伝統食品 であるべきと述べる。一見情緒的に思える 考え方である。

しかし、針塚氏の有機農業経営での特色 は、科学的であるべきであるということで ある。有機栽培の根拠が科学的に証明でき るなけらればならないと主張する。そのた めに、H A C C P 農法を提唱する。これはア メリカの N A S A で開発された手法であ り、日本の企業でも活用されている。

以上がセッションの報告の概要である。

会場からの意見と質問があった。林氏に 対しては、農協の加工事業におけるマーケ ティング意識の薄さが指摘された。農水産 業と企業との提携も、このようなマーケテ イングのノウハウを学ぶべきであるという 意見である。

また、斉藤氏には、それは大企業の手法で あり、中小企業には向かないのではないか 
という質問である。これに対しては、斉藤氏 の反論も行われた。針塚氏には、ビジネス界 の人々から、商材としての可能性について の質問が多かった。難しいテーマであった が、非常に有意義なセッションでの検討で あった。 